\title{
The Self-Regulated Learning of Younger Adolescents with and without Learning Difficulties - A Comparative Multiple Case Study
}

TANJA Č́ERnE ${ }^{1}$ AND MoJCA JuRIŠEviČ ${ }^{2}$

$\sim$ Well-developed self-regulated learning is the key to enabling learners to achieve both their educational goals and wider personal development. However, this can be especially challenging for adolescents with learning difficulties, because of the neuropsychological and neurophysiological characteristics of such individuals, as well as the significant disparities they tend to experience between the effort put into learning on the one hand, and the resulting learning achievements on the other. In the current comparative multiple case study, we researched the self-regulated learning of three younger adolescents with learning difficulties and that of one younger adolescent without learning difficulties. The data were subjected to triangulation methods and qualitative analysis, with the results showing that the younger adolescents with learning difficulties mainly used cognitive rehearsal strategies, while the organisational and elaboration strategies were used only with the aid of the available social resources. The results also show that metacognitive strategies with regard to planning, assessment, and self-regulation were not yet fully developed in the participants with learning difficulties. Two of the three younger adolescents with learning difficulties show several signs of defensive pessimism and learned helplessness. All the adolescents participating in this case study received support and help in their home environments and developed suitable selfencouragement and self-rewarding strategies through perceptions of their own success in their free-time activities. The participating teachers did not fully identify the strong areas and performance factors in the younger adolescents, both with and without learning difficulties. The results obtained from this case study might contribute to developing more efficient special-educational intervention approaches.

Keywords: self-regulated learning, younger adolescents with learning difficulties, comparative multiple case study

$1{ }^{\star}$ Corresponding Author. Counselling Centre for Children, Adolescents and Parents Ljubljana, Slovenia; tanja.cerne@scoms-lj.si.

2 University of Ljubljana, Faculty of Education, Slovenia. 


\section{Učna samoregulacija mlajših mladostnikov z učnimi težavami in brez njih}

TANJA ČERNE IN MOJCA JURIŠEviČ

$\approx$ Dobro razvita učna samoregulacija je ključna za doseganje izobrazbenih ciljev in osebni napredek učencev. Ta je pri mladostnikih z učnimi težavami zaradi nevropsiholoških in nevrofizioloških vzrokov ter zaradi pomembnih razlik med vlaganjem truda $\mathrm{v}$ učenje ter učnimi dosežki pogosto težje dosegljiva. V primerjalni multipli študiji primera smo raziskali učno samoregulacijo pri treh mlajših mladostnikih z učnimi težavami in pri enem mlajšem mladostniku brez učnih težav. Kvalitativna analiza na osnovi triangulacije metod in virov podatkov je pokazala, da mladostniki z učnimi težavami pri svojem učenju uporabljajo pretežno kognitivne strategije ponavljanja, organizacijske in elaboracijske strategije pa le s pomočjo uporabe socialnih virov. Metakognitivnih strategij načrtovanja, spremljanja in uravnavanja lastnega učenja še niso povsem razvili. Dva mladostnika $\mathrm{z}$ učnimi težavami sta kazala več znakov defenzivnega pesimizma in naučene nemoči. Mladostniki, udeleženi v raziskavi, so imeli podporo in pomoč domačega okolja; prek zaznave lastne uspešnosti so v okviru interesnih dejavnosti razvili ustrezne motivacijske strategije samopotrjevanja, samospodbujanja in samonagrajevanja. Sodelujoči učitelji niso povsem zaznavali močnih področij in dejavnikov uspešnosti mladostnikov $z$ učnimi težavami ter brez njih. Pridobljeni raziskovalni izsledki lahko prispevajo k oblikovanju učinkovitejših specialnopedagoških intervencijskih pristopov.

Ključne besede: učna samoregulacija, mlajši mladostniki z učnim težavami, primerjalna študija primera 


\section{Literature review}

Zimmerman (2000) defined self-regulation from the standpoint of socialcognitive learning and understands it as an interaction among people, behaviours and environmental processes (the influence of learning methods and practices, classroom atmosphere, and so on). He claims that lack of social experiences can lead to the dysfunction of self-regulated skills, and so create feelings of apathy and boredom, which are common among adolescents, both with and without learning difficulties (LD). Zimmerman and Martinez-Pons (1988) defined self-regulation through three general views of learning, which affect learning efficacy and the achievement of learning goals: self-regulated behaviour, self-regulated motivation, and self-regulated emotions. Wolters, Benzon, and Arroyo-Giner (2011) distinguished three components of self-regulated motivation: knowledge about motivation, observing motivation, and self-control of motivation. Strategies for self-regulated motivation are thus used by learners to increase their motivation and regulate their thoughts and activities towards goal achievement. Pintrich and DeGrott (1990) listed three components of self-regulation (metacognitive strategies for planning, observing and adapting one's mind; management and control of their efforts to carry out academic tasks; and the cognitive strategies used by learners when learning), and explain the influence of motivation on successful learning outcomes. Schunk and Ertmer (2000) underscored the importance of self-reflective practicing, especially in learners with LD, since their evaluation, reflection, and self-observance skills are less developed. Self-regulated learning (SRL) encourages the development of motivational learning strategies and enables the generalisation of the resulting knowledge to all learning areas. SRL includes a range of strategies, self-monitoring, self-reinforcement, self-awareness, self-efficacy, self-directed learning, self-determination, self-management, self-instruction and self-evaluation (Mitchell, 2014). Motivation regulation is a central concept in SRL and depends on the learner's knowledge about motivational processes and on their abilities to recognise, maintain, or to adapt their motivation to specific tasks and learning situations (Wolters, 2011). Motivational beliefs, beliefs about self-efficacy and the goals one has achieved are predictors of the application of self-regulated motivation (Paulino, Sá, \& Lopes da Silva, 2016). Metacognitive knowledge about motivation is thus essential with regard to enhancing SRL, since a learner is more likely to complete a school task effectively by choosing and applying appropriate self-regulated motivation strategies (Paulino et al., 2016). Motivation is linked to the perception of one's own efficacy attributional style, while perceived self-efficacy is defined as an individual's expectations about how successful they will be at in organisation and performance in certain tasks or 
activities, and in situations that include new, unexpected and stressful elements (Schunk \& Ertmer, 2000). Research shows that well-developed metacognitive abilities can influence how one anticipates the consequences of one's actions, improve the understanding of situations, activate already achieved knowledge, improve activity and time planning, and have a positive impact on the memory (Bransford, Brown, \& Cocking, 1999).

Boekaerts (1996) developed two models of SRL. First, she outlined a structural model in which self-regulation was divided into six components. There were organised around two basic mechanisms of SRL: cognitive and affective/motivational self regulation. The second SRL model, the Adaptable Learning Model, describes the dynamic aspects of SRL, and later, evolved into the Dual Processing self-regulation model. The Adaptable Learning Model offered a theoretical framework for understanding the findings from diverse psychological frameworks, including motivation, emotion, metacognition, self-concept, and learning (Boekaerts, 1996; Panadero, 2017).

In Slovene pedagogy, we distinguish between a general and specific learning difficulties. Attention deficit and hyperactivity disorder (ADHD) and problems caused by developmental delay (such adolescents tend to be slow learners) are examples of general learning difficulties. Examples of specific learning difficulties are problems caused by deficiency during the early development of auditory-motor processes, e.g., dyslexia (Magajna, Kavkler, Čačinovič-Vogrinčič, Pečjak, \& Bregar Golobič, 2008). Hereinafter, 'learning difficulties' refers to adolescents with dyslexia, adolescents with ADHD, and adolescents who are slow learners.

We will describe SRL, learning motivation and metacognition in adolescents with LD to answer research questions.

Adolescents with dyslexia often have problems in organising time for learning, study materials, and accessories (Raduly-Zorgo, Smythe, \& Gyarmathy, 2010) and thus with SRL. They have weak metacognitive awareness: they do not know, for example, how to approach a certain task (Reid, 2002). Reiter, Tucha, and Lange (2004) determined that adolescents with dyslexia experience difficulties in the areas of working memory, problem solving, inhibition, verbal and visual fluency, and thus with cognitive functions that are associated with the left prefrontal cortex. In adolescents with dyslexia, the external loci are more important, and they show less self-efficacy and use less effective motivational strategies (Sideridis, 2009).

Adolescents with attention deficit and hyperactivity disorder (ADHD) have insufficient self-control ability (i.e., a deficit in behavioural inhibition; Barkley, 2005), which can directly influence the occurrence of LD (Raggi \& Chronis, 
2006), and deficiencies in the areas of directing, maintaining and selecting attention. If an individual has several strongly negative experiences, then this can lead to very low self-esteem and self-image, or even depression (Peklaj, 2012; Reid, 2006). Moreover, insufficiencies in working memory and arousal influence can significanty decrease the learning-to learn ability (Carlson, Booth, Shin, \& Canu, 2002). Adolescents with ADHD do not learn from their own experiences.

Adolescents who are slow learners tend to act as passive receivers of knowledge. As such, they can assimilate basic learning skills and knowledge, but in a slower manner and not as thoroughly as their peers do. They need more time for learning, should be offered multi-sensory approaches (Malik, Rehman, \& Hanif, 2012), and require more practice and help in order to be successful (Shaw, 2010). They have general LD at different school subjects and in different fields of learning, showing problems with generalisation and subject matter transfer, and their information processing is slower than that seen in neurotypically developing individuals (Bonifacci \& Snowling, 2008; Cooter \& Cooter, 2004; Peklaj, 2012). They show less-developed metacognitive abilities, which include the planning, monitoring, and evaluation of their learning. Such adolescents are less motivated (Cooter \& Cooter, 2004), which could be a consequence of negative adverse experiences when the expectations of the environment are not fulfilled, and the amount of effort and exertion put into learning does not match their abilities (Peklaj, 2012).

\section{Research problem and research questions}

This study thus aims to analyse research data regarding the differences and similarities in SRL in younger adolescents (an adolescent with dyslexia, an adolescent with ADHD, and an adolescent who is a slow learner), and an adolescent without $\mathrm{LD}$ ) and to answer a research questions. To be more specific, we are comparing SRL within a group of adolescents with LD and the SRL taught to adolescents without LD. We are interested in the period in which adolescents rapidly develop their abilities of abstract and hypothetical thinking, planning, prediction of the consequences of their actions, reflecting on their own learning processes, engaging in productive introspection, accepting their own decisions and reducing the level of emotional dependence.

1. What are the differences or similarities in SRL in the group of younger adolescents with $\mathrm{LD}$, and individually in this case study?

2. What are the differences or similarities with regard to cognitive, metacognitive and motivational strategies, according to the cognitive and motivational structures seen in the four cases analysed in this case study? 
3. What kind of help do the home and school environments offer in creating, maintaining and changing the cognitive, metacognitive, and motivational learning strategies used by the four cases examined in this case study?

4. Does the school environment identify each adolescent's strengths and special needs, and encourage the development of dynamic adaptation processes, despite often difficult and threatening circumstances (due to the influence of the risk-resilience paradigm) in this case study?

\section{Research design and procedure}

We used a qualitative research approach and a comparative case study of three younger adolescents with LD and one younger adolescent without LD. We used the descriptive method of selective coding. The data were analysed by were qualitative content document analysis. Observing with participation was conducted in the individual situation. The author of this case study took the role of an observer and recorded short elaborations of the sentence during the observation and, on the same day, transcribed them into full notes. The author carried out semi-structured interviews with adolescents, parents, and teachers.

\section{Participants}

The current case study is a comparative study, which examined the issue of SRL in three younger adolescents with LD who were diagnosed and received team treatment in the Counselling Centre for Children, Adolescents and Parents, Ljubljana, and in one adolescent without LD. The teachers (of the last three grades of elementary school) who spend about two hours a week with these adolescents, prepare and monitor individualised programmes, also participated in this case study. They do not have specific knowledge in the field of special education. Parents of these adolescents also participated in the study. While both parents were invited, only the mothers took part in this study.

One of the participants, aged 14 years and 3 months, was diagnosed with dyslexia, and attended ninth grade (the final grade) of primary school in the 2015/16 school year. It is difficult to assess global intellectual abilities, due to high discrepancy (on the verbal scale: average, on the non-verbal scale: above average), changeable tempo in doing tasks, and diverted attention. Average grades are very good. He was assigned to a special education programme with an adjusted implementation of the curriculum and additional professional support.

Another participant, aged 14 years and 6 months, was diagnosed with ADHD, treated with pharmacological therapy, and also attended the ninth grade of primary school in the 2015/16 school year. He has average and below 
average verbal and non-verbal intellectual abilities. He has an impulsive style of doing exam tasks and problems with keeping selective attention. His average grade is good. He was assigned to a special education programme with an adjusted implementation of the curriculum and additional professional support.

The third participant with LD, aged 14 years and 5 months, was identified as a slow learner, and also attended the ninth grade of primary school in the 2015/16 school year, and had individual and group help in school. He has low average to below average intellectual abilities and major difficulties in verbal expression, comprehension, memorising, calculating, and working memory. His average grade is very good.

The fourth participant, aged 14 years and 6 months, had no LD, and thus was not treated in the Centre for Children, Adolescents and Parents, and was also in the ninth grade of primary school in the 2015/16 school year. He has normal intellectual abilities. His average grade is very good.

\section{Data collection method}

Data collection was conducted with triangulation and the use of various data resources, from January to June 2016. Informed consent was obtained from all the participants, and this research was conducted in compliance with the Code of Ethics for Researchers at the University of Ljubljana and following the general code of ethics in the field of sociology. Data collection was conducted in the Centre for Children, Adolescents and Parents, Ljubljana, where the interviews were carried out with the younger adolescents and their parents, as well as the observation of SRL and a documentation study. The following documents were surveyed: results of the psychological tests, reports of educational institutions, medical and other expert documentation on the basis of diagnostic examination. Observing with participation was conducted with the help of a control list, designed on the basis of the six-component adaptive learning model (Boekaerts, 1997) with regard to cognitive and motivational self-regulation, and the observation was carried out in three meetings with the research author. The observation was a part of the special-pedagogical diagnostic procedure. In individual situations, the author made the following observations: the content area of learning, cognitive strategies, cognitive regulation strategies, metacognitive knowledge and motivational believes, motivational strategies and motivational regulation strategies. Each adolescent received initial instructions as to how to learn about a specific subject. The adolescents were left to their own devices and not accompanied by their parents-mothers who participated in this case study. Telephone interviews were conducted with the classroom teachers at a convenient time, and with the consent of the participants' parents. 
All interviews were research-oriented, individual, direct and semi-structured (open- and close-ended type of questions).

The semi-structured interview that was done with each adolescent was structured on the basis of the four-component model of SRL (Hofer, Yu, \& Pintrich, 1998) with regard to the focal cognitive, motivational structure and motivational strategies, and contained 12 questions.

The semi-structured interviews with mothers were designed and conducted within the diagnostic process on the basis of the literature review on the issues of motivational regulation, regulation of resources from the environment, self-organisation and parents' expectations, and contained 10 questions.

The semi-structured interviews with the teachers were constructed based on the Rating Students Self-Regulated Learning Outcomes/Self-Regulated Learning Outcomes - A Teacher Scale; (Zimmerman \& Martinez Pons, 1988), with regard to the frameworks of learning organisation, self-initiative, interest, and seeking help, and contained 10 questions.

\section{Data-processing Procedure}

Data processing was conducted using a descriptive method of selective or focused coding in which we emphasised the codes that occur most frequently and those that tell the most about the research material (Vogrinc, 2008). Coding was conducted using a deductive approach on the basis of the prepared list of codes, as well as the relevant professional literature. All interviews were analysed using qualitative analysis, with word-for-word transcriptions and the retention of any colloquial expressions used by the participants. The basic coding categories were developed based on a review of the literature. The interview transcripts were analysed with the help of condensation and categorisation (Kvale, 1996). The documentation study was conducted following the steps of qualitative context documentation analysis.

\section{Results}

Qualitative data was obtained from the comparative study case with regard to the SRL of the younger adolescents with and without LD, which will be helpful for the further research and development of effective approaches in the context of special-educational interventions. Moreover, triangulation of the methods and approaches applied means that more valuable and reliable research data was gained in this process.

On the basis of the documentation survey, it can be concluded that all the participating adolescents with LD have individual learning help or 
additional professional help, that they receive didactic-methodical adjustments and modifications regarding knowledge assessment and evaluation, are treated in the Centre for Children, Adolescents and Parents, Ljubljana, have strong fields of interest and intense home help and support. The adolescent without LD has no learning help, except for occasional assistance provided within the family. All four adolescents decided to continue their education in suitable high school programmes.

Acording to the transcripts of the interviews with the adolescents with LD and the adolescents without LD and the child without LD who participated in this case study, have support and help offered by the home environment with regard to establishing effective motivational, cognitive and metacognitive learning strategies. Overall, the parents' expectations encourage the younger adolescents examined in this study to show greater independence and responsibility. Based on the answers that were obtained, three main categories of homebased support were identified, as follows:

A) Home support in learning, as defined by the mother of the adolescent with dyslexia: 'Everything has to be looked upon positively ... I always say to him, even if you did something wrong, tell me, because everything can be solved.' The mother of the adolescent with ADHD noted: 'I help him with learning; when he gets a good grade, his self-esteem rises.' The mother of the adolescent who is a slow learner stated: 'He needs regular help with reading and reading comprehension. Both my husband and I regularly check his knowledge of the current subject matter.' Finally, the mother of the adolescent without LD said: 'I encourage him regularly, meet with teachers in office hours where I am informed if he does his homework or not and then we talk about it at home. Brothers and sisters help if needed.'

B) Organisation of learning, as defined by the mother of the adolescent with dyslexia: 'He has a monthly and weekly plan of learning. When he lacks energy, he needs to be encouraged, especially in subjects he doesn't like. He studies in his room, with light music in the background.' The mother of the adolescent with ADHD said: 'He studies more or less regularly, on a daily basis, depending on the motivation and contact with the teacher. He studies in his room. Studying is organised according to his training sessions.' The mother of the adolescent who is a slow learner stated: 'He is doing his homework more regularly this school year. My husband and I do not check his homework. He studies independently only if he is reminded to. He studies in his room or in the living room when we revise the subject matter ... Finally, the mother of the adolescent without LD noted: 'He studies regularly this school year. He is committed and 
persistent, especially with the subjects where he is successful. He studies in his room, in the evenings, and he does his homework when he comes home from school.'

C) Learning goals and further schooling, as defined by the mother of the adolescent with dyslexia: 'His goal is to attend school abroad (his brothers are his role models) ...' The mother of the adolescent with ADHD said: 'He cannot wait to finish primary school and change the environment ... It is important to be inventive and to be hardworking. The mother of the adolescent who is a slow learner explained: 'He learns independently the subject matter he finds interesting. We encourage him to use the computer. We wish he was independent, inventive and would not come under the influence of some bad person. Finally, the mother of the adolescent without LD stated: 'I wish he would improve his working and learning habits. That he wouldn't rely on other's people opinions, but his own'

The transcripts of the interviews with the teachers show that the adolescents with LD, who participated in this case study, are passive in learning, do not seek additional information and help, are less motivated with regard to learning, and less persistent, and that it is only in the final year of primary school that they have been acquiring organisational and SRL habits. The adolescents without LD was able to pay attention and took an active part in the classes. On the basis of the participants' answers, two main categories of passive or active learning were created, as follows:

A) Seeking more information, as defined by the teacher of the adolescent with dyslexia: 'He doesn't seek additional information, doesn't put himself forward, is passive in class. He doesn't ask for help from the teacher or peers, perhaps his schoolmates ... I don't know him very well, because he doesn't take part in excursions, where I can learn about the students more.' The teacher of the adolescent with ADHD stated: 'He is passive in classes, doing only the tasks given. More interest is noticed in English class, which is his strongest field. He doesn't seek help from peers and teachers. His mom organises the notes for him.' The teacher of the adolescent who is a slow learner explained: 'He doesn't ask about the exam assessment details. He is quickly satisfied with task demands and doesn't seek additional information. A passing grade is enough for him. He follows instructions, is passive and compliant.' Finally, the teacher of the adolescent without LD said: 'He doesn't seek additional information, is hardworking and many times a role model to his classmates. He follows the instructions and asks for help from the teacher or peers.' 
B) Learning organisation, self-regulation and motivation, as defined by the teacher of the adolescent with dyslexia: 'He doesn't do all his duties before the deadline, because he often gets sick. He doesn't do the best at learning. He listens in class and makes notes, he doesn't put himself forward and is not active. He makes agreements about the dates of his oral exams independently. He rarely volunteers for additional assignments, because he has a lot of free-time obligations.' The teacher of the adolescent with ADHD stated: 'In the past, he postponed studying - it is better now. He doesn't do his homework regularly. He has bad learning strategies and quickly gives up. He is passive in class, reserved, doesn't ask questions. He makes agreements about his oral examinations independently. He had problems in the previous school as well and was anxious and consequently failed to be present at school.' The teacher of the adolescent who is a slow learner reported: 'This school year he is doing the assignments more regularly and is showing more self-initiative. He makes agreements about adjustments in the class and minimal or basic knowledge standards independently. With individual help, he says that he has no interest in the subject matter and that he doesn't like literature.' Finally, the teacher of the adolescent without LD stated: 'In this school year he does his homework regularly, follows the class demands, has his school accessories and plans his learning. He cooperates and listens in class.'

The transcripts of the answers given by the younger adolescents are in Table 1, which shows a summary of the different compensation strategies used for learning, including both cognitive and semi-cognitive learning strategies, with their parents provided help in this regard. The transcripts also show that the adolescents want to understand the focal subject matter and use it in practical situations. Two of the adolescents with LD expressed a clear fear of failure and feelings of helplessness with regard to specific school subjects, showing several signs of defensive pessimism and learned helplessness. All the participating adolescents had developed suitable motivational strategies with regard to self-affirmation, self-encouragement and self-awarding, by identifying their successes in their areas of interest. 
Table 1

Transcription of the answers from the semi-structured interviews with the younger adolescents

\begin{tabular}{|c|c|c|c|c|}
\hline & $\begin{array}{l}\text { Cognitive } \\
\text { structure }\end{array}$ & $\begin{array}{l}\text { Cognitive, } \\
\text { metacognitive } \\
\text { strategies }\end{array}$ & $\begin{array}{l}\text { Motivational } \\
\text { structure }\end{array}$ & $\begin{array}{l}\text { Motivational } \\
\text { strategies }\end{array}$ \\
\hline $\begin{array}{l}\text { Adolescent } \\
\text { with } \\
\text { dyslexia }\end{array}$ & $\begin{array}{l}\text { - It is important } \\
\text { to me to say } \\
\text { the subject } \\
\text { material in my } \\
\text { own words, } \\
\text { and to tell } \\
\text { myself the } \\
\text { main points. }\end{array}$ & $\begin{array}{l}\text { - I write down } \\
\text { the main } \\
\text { points of the } \\
\text { subject matter. } \\
\text { - When I don't } \\
\text { understand, I } \\
\text { ask classmates } \\
\text { or use the } \\
\text { Internet. }\end{array}$ & $\begin{array}{l}\text { - Before the oral } \\
\text { exam, I was fine. The } \\
\text { moment I sat down } \\
\text { at the desk, my } \\
\text { head started to spin, } \\
\text { a force was pulling } \\
\text { me to the left and I } \\
\text { almost fell, I was so } \\
\text { scared. } \\
\text { - Sometimes I cannot } \\
\text { sleep a week before } \\
\text { the exam. }\end{array}$ & $\begin{array}{l}\text { - I study regularly, } \\
\text { sometimes I doubt } \\
\text { my success. But } \\
\text { mostly not. } \\
\text { - I believe I would } \\
\text { postpone studying if } \\
\text { I didn't have training, } \\
\text { and it would be } \\
\text { harder to organize } \\
\text { my time. }\end{array}$ \\
\hline $\begin{array}{l}\text { Adolescent } \\
\text { with ADHD }\end{array}$ & $\begin{array}{l}\text { - History is } \\
\text { hard for me to } \\
\text { learn, because } \\
\text { I mess up the } \\
\text { data or forget } \\
\text { the years. } \\
\text { - I do a lot of } \\
\text { exercises at } \\
\text { Math to really } \\
\text { get familiar } \\
\text { with it. } \\
\text { - It is easier } \\
\text { to me not to } \\
\text { learn from the } \\
\text { books only, } \\
\text { but also the } \\
\text { way we did at } \\
\text { summer camp } \\
\text { school. }\end{array}$ & $\begin{array}{l}\text { - Mom makes } \\
\text { me notes } \\
\text { because I get } \\
\text { confused. } \\
\text { - I underline im- } \\
\text { portant words } \\
\text { and write the } \\
\text { explanations. } \\
\text { I like it if there } \\
\text { is not a lot of } \\
\text { text. }\end{array}$ & $\begin{array}{l}\text { - I don't know if I can } \\
\text { learn everything. } \\
\text { When I get a bad } \\
\text { grade, my motiva- } \\
\text { tion falls. } \\
\text { - I influence my suc- } \\
\text { cess by listening in } \\
\text { school, focusing, } \\
\text { and studying. }\end{array}$ & $\begin{array}{l}\text { - I try to put more } \\
\text { energy into learning. } \\
\text { I don't go out during } \\
\text { the week, like my } \\
\text { classmates do. } \\
\text { - Sometimes it hap- } \\
\text { pens that my goals } \\
\text { are too high for my } \\
\text { knowledge. } \\
\text { - I wish I had good } \\
\text { grades but it doesn't } \\
\text { work. } \\
\text { - At sport, I get power } \\
\text { and motivation when } \\
\text { I am good at what } \\
\text { I do. Sport means } \\
\text { relaxation to me; to } \\
\text { forget about school. } \\
\text { It is easier to me to } \\
\text { express my feelings } \\
\text { with dancing. }\end{array}$ \\
\hline $\begin{array}{l}\text { Adolescent } \\
\text { who is a } \\
\text { slow learner }\end{array}$ & $\begin{array}{l}\text { - In History, I } \\
\text { use familiar } \\
\text { words to help } \\
\text { me remember } \\
\text { the text. } \\
\text { - In Math, my } \\
\text { father helps } \\
\text { me by giving } \\
\text { me exercises } \\
\text { that I practice } \\
\text { until I can do } \\
\text { them. }\end{array}$ & $\begin{array}{l}\text { - First, I study } \\
\text { what is easy, } \\
\text { and then what } \\
\text { is hard. } \\
\text { - Mom and } \\
\text { Dad and my } \\
\text { teacher in } \\
\text { school make } \\
\text { notes for me. }\end{array}$ & $\begin{array}{l}\text { - I don't like music } \\
\text { classes and I am } \\
\text { not interested, and } \\
\text { this is why I think I } \\
\text { can't learn it. I study } \\
\text { just before the oral } \\
\text { exam. } \\
\text { - Learning about the } \\
2^{\text {nd }} \text { World War in } \\
\text { History was easy for } \\
\text { me, because I was } \\
\text { interested and I got } \\
\text { a very good grade. }\end{array}$ & $\begin{array}{l}\text { - When studying, I al- } \\
\text { ways think positive. } \\
\text { - I am successful in } \\
\text { Computer Science, } \\
\text { where the teacher } \\
\text { gave me a chance to } \\
\text { clean the computers. }\end{array}$ \\
\hline
\end{tabular}




\begin{tabular}{lllll}
\hline & $\begin{array}{l}\text { Cognitive } \\
\text { structure }\end{array}$ & $\begin{array}{l}\text { Cognitive, } \\
\text { metacognitive } \\
\text { strategies }\end{array}$ & $\begin{array}{l}\text { Motivational } \\
\text { structure }\end{array}$ & $\begin{array}{l}\text { Motivational } \\
\text { strategies }\end{array}$ \\
\hline Adolescent & - When study- & - I read the & - I am nervous before & - A good grade \\
without LD & ing, it is & subject matter & oral exams and & motivates me to \\
& important to & aloud and & get lower grades, & learn more easily; \\
& understand & repeat it. & compared to written & otherwise I know I \\
the subject & - I know I have & tests. & have to study to be \\
& matter and & to do my best & - When I am anxious, & successful in life. \\
& to use the & and to learn & I revise or tell myself & \\
knowledge. & regularly. & a positive thought. & \\
\hline
\end{tabular}

Due to the results of the observation with participation, the following details were observed (Table 2): Younger adolescents with LD partly use declarative and procedural knowledge (with help from their social resources), while the adolescent without LD also uses conceptual knowledge. All the adolescents use the strategy of repetition, and to some extent also the organisational and elaborative strategies. The motivational beliefs in younger adolescents with LD are less effective and provide less learning support in comparison to that seen in the child without LD. Here it should be noted that the motivational strategies the adolescents used are mainly established based on the help provided by the social resources available in the home environment. The applied motivational regulation strategies differ among the three adolescents with LD, since one of them has quite a clear understanding of the goal of such strategies, whereas the other two need help from their social environments to connect their behavioural intentions with the plans they have for their learning activities. In contrast, the younger adolescent without LD is able to take care of his own learning activities plan, which he sometimes changes as the need arises.

Table 2

\section{Observation with participation - six-component adaptable learning model}

\author{
3. Cognitive regulation strategies \\ Adolescent with dyslexia: creates activity plans \\ for individual subjects; monitors his progress; \\ assesses his goal achievements; is aware of his \\ strong areas, deficiencies, and compensation \\ strategies. \\ Adolescent who is a slow learner: studies \\ without any activity plans, mainly before tests \\ or other assessments; is aware of the need for \\ regular studying, which he partially achieves. \\ Adolescent with ADHD: his mental representa- \\ tion of his learning goals is not clear, and these \\ goals are not specific, and are simply aimed at \\ getting good grades; his activity plans are linked \\ to the effort and time he puts into learning. \\ Adolescent without LD: his activity plans are \\ linked to his regular educational goals.
}

\section{Motivational regulation strategies}

Adolescent with dyslexia: keeps to his activities plans regardless of the obstacles met, since he keeps in mind a mental representation of the goal.

Adolescent who is a slow learner: this learner's goal-orientation with regard to learning is linked to topics of interest in the subject matter; individual facts attract his attention and increase his desire to remember them and learning more effectively.

Adolescent with ADHD: his mother helps him connect his behavioural intentions with his activity plans for learning; the child stated that the goals for his grades are too high.

Adolescent without LD: his activity plans change when obstacles are encountered. 


\begin{tabular}{|c|c|}
\hline $\begin{array}{l}\text { 2. Cognitive strategies } \\
\text { Adolescent with dyslexia: uses organizational } \\
\text { and elaborative strategies (with help from } \\
\text { parents and tutors); uses the strategies of self- } \\
\text { checking and repetition. } \\
\text { Adolescent who is a slow learner: uses organiza- } \\
\text { tional and elaborative strategies (with help from } \\
\text { parents and teachers) and repetition strategies } \\
\text { (independently). } \\
\text { Adolescent with ADHD: mainly uses repetition } \\
\text { strategies, and sometimes elaborative and orga- } \\
\text { nizational strategies (with help from his mother). } \\
\text { Adolescent without LD: mainly uses repetition } \\
\text { strategies, and rarely applies other approaches. }\end{array}$ & $\begin{array}{l}\text { 5. Motivational strategies } \\
\text { Adolescent with dyslexia: creates his own learn- } \\
\text { ing intentions, such as goals that are connected } \\
\text { with his further education; uses help from vari- } \\
\text { ous social resources (mother, tutor, and special } \\
\text { education teacher). } \\
\text { Adolescent who is a slow learner: avoids and } \\
\text { postpones learning; uses help from social } \\
\text { resources (both parents and teacher). } \\
\text { Adolescent with ADHD: often has negative } \\
\text { feelings and anxiety, which he cannot regulate } \\
\text { by himself, and this is why he needs modified } \\
\text { assessments and tests; uses his social resources } \\
\text { (parents and teacher). } \\
\text { Adolescent without LD: avoids regular effort; } \\
\text { less use of social resources; uses a suitable at- } \\
\text { tributional style. }\end{array}$ \\
\hline $\begin{array}{l}\text { 1. Content fields } \\
\text { Adolescent with dyslexia: uses procedural and } \\
\text { declarative knowledge; concepts about learning } \\
\text { are linked to the use of knowledge in real life. } \\
\text { Adolescent who is a slow learner: sometimes } \\
\text { uses declarative knowledge and procedural } \\
\text { knowledge (with parents' help). Concepts about } \\
\text { learning and learning motivation are linked to } \\
\text { the teacher of the subject. } \\
\text { Adolescent with ADHD: needs a lot of practice } \\
\text { to remember procedural knowledge; declarative } \\
\text { knowledge is partly gained, since it is linked to } \\
\text { weak processes of remembering and forgetting. } \\
\text { Adolescent without LD: uses procedural and } \\
\text { conceptual knowledge. }\end{array}$ & $\begin{array}{l}\text { 4. Metacognitive knowledge and motivational } \\
\text { beliefs } \\
\text { Adolescent with dyslexia: his beliefs about } \\
\text { learning more difficult subjects are linked to ex- } \\
\text { trinsic motivation; his goal-orientation is to finish } \\
\text { primary school and continue schooling. } \\
\text { Adolescent who is a slow learner: his beliefs } \\
\text { about his own learning capacities are over- } \\
\text { estimated. } \\
\text { Adolescent with ADHD: his negative beliefs } \\
\text { about his attention capacities, memory, motiva- } \\
\text { tion and learning efficacy increase the anxiety } \\
\text { he feels. } \\
\text { Adolescent without LD: his beliefs about his } \\
\text { capacities correspond to the use of strategies } \\
\text { and are goal-oriented. }\end{array}$ \\
\hline
\end{tabular}

\section{Findings that relate to SRL in individual adolescents}

The younger adolescent with dyslexia, who has a great deal of support from his home environment, in addition to professional support and extra tutoring hours, uses various cognitive learning strategies and a number of metacognitive learning strategies, but only partly uses the motivational strategies of self-obstruction, defensive pessimism, and learned helplessness. In contrast, he uses strategies of self-affirmation to a greater extent, especially with regard to sports. This adolescent is also able to define well the acquisition of declarative, procedural knowledge, and knowledge about circumstances. This participant's implicit conceptions of learning encourage him to develop his learning-to-learn competence. Moreover, his motivational structure is shaped by beliefs in his own efficacy in some school subjects, interest in learning, and a positive goalorientation on terms of setting learning and personal goals. While the teacher noted the adolescent's passivity in a school context, the results of the observations, documentation survey, and questionnaires indicate that this individual is an active learner, showing initiative and applying adequately developed 
cognitive, metacognitive and motivational strategies, along with an appropriate attributional style. It is possible that this adolescent felt some test anxiety, which reduced his ability to engage in active learning and to show initiative, with both these being important components of academic self-esteem, and this would fit with research findings in the literature about significantly decreased learning self-esteem in learners with LD (Chapman, 1988).

The younger adolescent with ADHD uses the most strategies related to seeking help, and especially support from home, and this is because of his learned helplessness, defensive pessimism and feelings of test anxiety, as expected according to the manifestation and symptoms of ADHD. This is why this adolescent is less independent and more passive at learning, although it should be noted that, from a developmental perspective, he showed signs of gaining insights into various learning-to-learn competencies, and gradually changed from conscious incompetence to conscious competence. He uses cognitive strategies of repetition independently, while he applies the organisational and elaborative strategies with the help of the home environment. The adolescent's metacognitive strategies of planning, monitoring and regulating his own learning have not been developed yet, due to his problems with regard to an attention deficit, hyperactivity and test anxiety. He attributes his learning success to internal and external factors, which hinders his own progress as an independent learner. Finally, the motivational strategy of self-affirmation helps this learner with ADHD to feel protected, and thus experience success.

The adolescent who is a slow learner shows less insight into his cognitive structure of learning, due to his poorer cognitive functions, uses simpler cognitive learning strategies, and needs external help to direct his learning. This adolescent's metacognitive strategies of planning, monitoring, and regulating learning have not yet been developed, although he has made some progress in these areas. Moreover, the boy's beliefs about his own efficacy are not entirely realistic, while his goal-orientation is linked to rather narrow educational interests. The use of the strategies of goal-oriented monologue and encouragement have been able to maintain this adolescent's interest in learning, and overall these conclusions are supported by the comments of the boy's mother and teacher with regard to self-regulation.

Finally, the adolescent without LD does not recognise his cognitive, metacognitive and motivational strategies, but uses some of them, in line with the findings reported in the review of the literature. He applies a beneficial attributional style, supported by a realistic understanding of his own self-esteem, suitable beliefs about his efficacy, and appropriate personal and learning goals within his home and school environment. 


\section{Discussion and conclusion}

This study offers insights into the SRL of four younger adolescents, three with LD and one without. Moreover, on the basis of its qualitative analysis with regard to the cognitive, self-regulative, metacognitive, and motivational strategies used by the adolescents, as gained by triangulation of both methods and resources, this study presents a clear outline of the participants' self-regulation skills (Boekaerts \& Cascallar, 2006; Garcia Duncan, \& McKeachie, 2005). The results obtained via observation give an objective picture of what learners did, in contrast to what teachers and mothers assumed learners thought they usually do. The results confirm the significant impact of parents' active participation in the education of their children, with this resulting in greater achievement and more motivation in a school context (Grolnick, Deci, \& Ryan, 1991). The findings with regard to each case also confirm that the adolescents with LD who participated in this case study often put more effort and energy into seeking help from their peers and adults when doing schoolwork, or even attempt to convince others to complete their schoolwork for them (Grašič et al., 2010). All the adolescents with LD in this study tend to use cognitive strategies related to repetition of the subject matter, and only apply cognitive and elaboration strategies with the aid of social resources.

In general, the adolescents with LD show the motivational strategies of learned helplessness, test anxiety and defensive pessimism, which are congruent with the findings in the literature (Borkowski \& Thorpe, 1994). These children also have a higher probability of feeling stress, as reported by themselves, and social conflicts, as reported by their teachers and parents, and thus more efforts need to be made to provide them with a familiar and safe environment within which learning can occur (Grolnick et al., 1991). All the adolescents who participated in this study show developed motivational strategies of self-confirmation, enabling them to protect their own self-esteem based on areas other than school. The teachers describe all the children as passive learners, with insuficient learning motivation and unsuitable organisation and SRL strategies. The learners are thus not able to identify their strong areas or sucess factors, which is possible reason for the co-occurence of secondary LD (test anxiety, passivity, and learned helplessness).

The intervention models in Slovenia that have currently been developed, which some primary and secondary schools have started to introduce, encourage the early development of some of the skills needed to cope efficiently with problems, search for various solutions when difficulties arise, and enhance the learners' skills with regard to assertiveness and communication (Kiswarday 
Riccarda, 2012), all of which is important for adolescents with LD, both for their present and future schooling, as well as their personal and professional lives. The findings of this study can serve as a basis for defining guidelines for the provision of additional professional help in encouraging children to achieve higher educational goals, to counsel parents to assist their children with LD to become more independent, and to help teachers as they attempt to understand, make realistic assessments of, and encourage the development of adolescents with LD. Such moves could help prevent chain reactions (Kiswarday Riccarda, 2012) that can cause more secondary LD, such as emotional and behavioural problems (Magajna, 2015). Since this is a case study, we emphasise that the conclusions are based on a small number of cases and thus cannot be applied to an entire population with similar characteristics. With regard to future research in this area, further studies should aim to collect comparative data from a larger sample of adolescents with LD. Moreover, more precise observations are needed of the various behavioural indicators that indicate the use of SRL strategies in different groups of younger adolescents with LD, with a focus on the related contextual factors.

\section{Acknowledgments}

The author expresses her gratitude to the adolescents participating in this research, as well as their mothers and teachers, and those who provided additional professional help. Part of this article was presented as a poster at the ICIE conference 2016.

\section{References}

Barkley, R. A. (2005). ADHD and the nature of self-control. New York, NY: Guilford Press.

Boekaerts, M. (1996). Self-regulated learning at the junction of cognition and motivation. European Psychologist, 1(2), 100-112.

Boekaerts, M., \& Cascallar, E. (2006). How far have we moved toward the integration of theory and practice in self-regulation? Educational Psychology Review, 18(3), 199-210.

Bonifacci, P., \& Snowling, M. J. (2008). Speed of processing and reading disability: A cross-linguistic investigation of dyslexia and borderline intellectual functioning. Cognition, 7(3), 999-1017.

Borkowski, J. G., \& Thorpe, P. K. (1994). Self-regulation and motivation: A life span perspective on underachievement. In D. H. Schunk \& B. J. Zimmerman (Eds.), Self-regulation of learning and performance: Issues and educational applications (pp. 45-75). Hillsdale, NJ: L. Erlbaum Associates. Bransford, J., Brown, A. L., Cocking, R. R., \& National Research Council (U.S.) (1999). How people learn: Brain, mind, experience, and school. Washington, DC: National Academy Press. 
Carlson, C. L., Booth, J. E., Shin, M., \& Canu, W. H. (2002). Parent- teacher- and self-rated motivational styles in ADHD subtypes. Journal of Learning Disabilities, 35(2), 104-113.

Chapman, J. W. (1988). Learning disabled children's self-concepts. Review of Educational Research, 58 , 347-371.

Cooter, K. S. \& Cooter, R. B. (2004). One size doesn't fit all: Slow learners in the reading classroom. Reading Teacher, 57(7), 680-684.

Garcia Duncan, T., \& McKeachie, W. J. (2005). The making of the Motivated strategies for learning questionnaire. Educational Psychologist, 4o(2), 117-128.

Grašič, A., Kavkler, M., Magajna, L., Lipec-Stopar, M., Bregar-Golobič, K., Čačinovič-Vogrinčič, G., \& Janželj, L. (2010). Težave dijakov pri učenju v poklicnem in strokovnem izobraževanju: opredelitev, prepoznavanje, oblike in mreža pomoči (analiza stanja) [Learning difficulties of the students in career and technical education: definition, recognition, forms and network of help (situation analysis)] (Research report). Retrieved from http://www.cpi.si/files/cpi/userfiles/Datoteke/Publikacije/Tezave_ dijakov_pri_ucenju_raziskovalno_porocilo.pdf

Grolnick, W. S., Deci, E. L., \& Ryan, R. M. (1991). The inner resources for school performance: Motivational mediators of children's perceptions of their parents. Journal of Educational Psychology, $83(4), 508-519$.

Hofer, B., Yu, S., \& Pintrich, P. R. (1998). Teaching college students to be self-regulated learners. In D. H. Schunk \& B. J. Zimmerman (Eds.), Self-regulated learning: From teaching to self-reflective practice (pp. 57-86). New York, NY: Guilford Press.

Kiswarday, Riccarda, V. (2012). Stališča učiteljev do možnosti razvijanja rezilientnosti pri učencih in dijakih [Teachers'attitudes towards the possibilities of developing resilience in pupils and students. Unpublished Doctoral Dissertation.] Ljubljana: Pedagoška Fakulteta Univerze v Ljubljani.

Kvale, S. (1996). InterViews: An introduction to qualitative research interviewing. Thousand Oaks, CA: Sage.

Magajna, L., Kavkler, M., Čačinovič-Vogrinčič, G., Pečjak, S., \& Bregar Golobič, K. (Eds.) (2008). Učne težave v osnovni šoli: koncept dela [Special needs in elementary school: the concept of work]. Ljubljana: Zavod republike Slovenije za šolstvo.

Magajna, L. (2015). Sodobne raziskave spoznavnih procesov in psiholoških virov pri specifičnih motnjah učenja: izzivi za razvojno delo in prakso. In Z. Pavlović (Ed.), 6o let podpore pri vzgoji, učenju in odraščanju [6o years of supporting education, learning and growing-up] (pp. 141-160). Ljubljana: Svetovalni center za otroke, mladostnike in starše Ljubljana.

Malik, N. I., Rehman, G., \& Hanif, R. (2012). Effect of academic interventions on the developmental skills of slow learners. Pakistan Journal of Psychological Research, 27(1), 135-151. Retrieved from http:// www.pjprnip.edu.pk/pjpr/index.php/pjpr/article/viewFile/37/29

Mitchell, D. (2014). What really works in special and inclusive education: Using evidence-based teaching strategies. London, UK: Routledge.

Paulino, P., Sá, I., \& Lopes da Silva, A. (2016). Self- regulation of motivation: Contributing to students' learning in middle school. The European proceedings of social and behavioural sciences EpSBS. Retrieved 
from Future Academy website: http://dx.doi.org/10.15405/epsbs.2016.05.1

Panadero, E. (2017). A review of self-regulated learning: Six models and four directions for research.

Frontiers in Psychology, 8, 422. Retrieved from https://www.ncbi.nlm.nih.gov/pmc/articles/ PMC5408091/

Peklaj, C. (2012). Učenci z učnimi težavami v šoli in kaj lahko stori učitelj [Learners with learning difficulties in school and what a teacher can do]. Ljubljana: Filozofska fakulteta Univerze v Ljubljani. Pintrich, P., \& De Groot, E. (1990). Motivational and self-regulated learning components of classroom academic performance. Journal of Educational Psychology, 82(1), 33-40.

Raggi, V. L., \& Chronis, A. M. (2006). Interventions to address the academic impairment of children and adolescents with ADHD. Clinical Child and Family Psychology Review, 9(2), 85-111.

Raduly-Zorgo, E., Smythe L., \& Gyarmathy, E. (2010). Disleksija - vodnik za tutorje [Dyslexia - a guide for tutors]. Ljubljana: Društvo Bravo.

Reid, G. (2002). Nekaj v prijateljsko pomoč - vodnik za starše otrok $z$ disleksijo [With a little help from my friends - A guide for parents of dyslexic children] Ljubljana: Društvo Bravo.

Reid, G. (2006). Managing attention difficulties in the classroom: A learning styles perspective. In G. Lloyd \& G. J. Stead (Eds.), Critical new perspectives on AD/HD (pp. 198-215). London, UK: Routledge. Reiter, A., Tucha, O., \& Lange, K. (2004). Executive functions in children with dyslexia. Dyslexia, 11, 116-31.

Schunk, D. H., \& Ertmer, P. A. (200o). Self-regulation and academic learning. In M. Boekaerts, P. R. Pintrich, \& M. Zeidner (Eds.), Handbook of self-regulation (pp. 631-646). San Diego, CA: Academic Press.

Sideridis, G. D. (2009). Motivation and learning disabilities: Past, present, future. In K. R. Wentzel \& A. Wigfield (Eds.), Handbook of motivation at school (pp. 604-625). New York, NY: Routledge.

Shaw, S. R. (2010, February). Rescuing students from the slow learner trap. Principal Leadership, 12-16. Retrieved from https://www.nasponline.org/Documents/Resources\%20and\%2oPublications/ Handouts/Families\%2oand\%2oEducators/Slow_Learners_Feb1o_NASSP.pdf

Vogrinc, J. (2008). Kvalitativno raziskovanje na pedagoškem področju [Qualitative research in the area of education]. Ljubljana: Pedagoška fakulteta Univerze v Ljubljani.

Wolters, C. A. (2011). Regulation of motivation: Contextual and social aspects. Teachers College Record, 113(2), 265-283. Retrieved from http://www.tcrecord.org/library/Abstract.asp?ContentId=15977 Wolters, C. A., Benzon, M. B., \& Arroyo-Giner, C. (2011). Assessing strategies for the self-regulation on motivation. In D. H. Schunk \& B. Zimmerman (Eds.), Handbook of self-regulation of learning and performance (pp. 298-313). New York, NY: Routledge.

Zimmerman, B. J. (2000). Attaining self-regulation: A social cognitive perspective. In M. Boekaerts, P. R. Pintrich, \& M. Zeidner (Eds.), Handbook of self-regulation (pp. 31-40). San Diego, CA: Academic Press.

Zimmerman, B. J., \& Martinez-Pons, M. (1988). Construct validation of a strategy model of student self-regulated learning. Journal of Educational Psychology, 8o(3), 284-29o. 


\section{Biographical note}

TANJA ČERNE is a professor of special and rehabilitation education, employed at the Counselling Centre for Children, Adolescents and Parents in Ljubljana and has extensive clinical experience in assessment, counselling of learning difficulties. She is a PhD student at the Faculty of Education, University of Ljubljana and Assistant in the Department of Special education at the Faculty of Education, University of Ljubljana. She participates in numerous consultations, seminars and lectures on specific learning difficulties for parents, teachers and school counsellors and runs workshops for students with learning difficulties.

MojCa JurišEvič, PhD, is Full Professor of Educational Psychology at the University of Ljubljana, Faculty of Education. Her research interests span the fields of learning and teaching with studies focusing mainly on topics of motivation to learn, creativity, gifted education, mentoring, and (student) teacher professional development. She is the founder and the faculty director of the Centre for Research and Promotion of Giftedness. She is a member of the Council of the European Talent Support Network and a national coordinator of the World Council for Gifted and Talented Children. She serves as the Chair of the division "Psychologists in Education" of the Slovenian Psychologists' Association, and as the member of Standing Committee of Psychology in Education at European Federation of Psychologists' Associations. She is also an affiliated member of the American Psychological Association (Division 15). 